\title{
The Effect of Green Marketing, Brand Image, and Atmosphere Store On Purchasing Decisions In Arei Adventure Store Surabaya 3
}

\author{
Yanuar Bachrul Aqsony ${ }^{*}$, Santirianingrum Soebandhi, Ani Wulandari \\ Faculty of Economics and Business, Narotama University, Surabaya, Indonesia
}

\begin{abstract}
Purchasing decisions are one thing that is very influential in a product. Many factors influence purchasing decisions, including green marketing activities, brand image, and store atmosphere. The purpose of this study was to determine how the influence of green marketing, brand image, and store atmosphere both simultaneously and partially on purchasing decisions at Arei Adventure Store Surabaya 3. Data collection used was a questionnaire. The research method employed a random sample of 101 people. The analytical method mobilized was SPSS 24. The results of this study indicated that the independent variables simultaneously influence the dependent variable. This was evidenced from the significance value of 0,000 or less than 0.05 and $F$ count $=27.791$ while the $\mathrm{F}$ value was obtained at 2.70. Thus $\mathrm{F}$ count $27.791>\mathrm{F}$ table 2.70 . However, partially the green marketing variable was not significant to the purchase decision because the test results showed the value of $\mathrm{t}$ count $=1.425<\mathrm{t}$ table 1.98472 with a significance of $0.157>0.05$.
\end{abstract}

Keywords: green marketing, store atmosphere, brand image, purchase decision.

\section{Introduction}

Data from Jenna R Jambeck, University of Georgia states that China is the largest country in the world as a producer of waste in the ocean (262.9 million tons), the Philippines ranks 3rd (83.4 million tons), followed by Vietnam ranked at the fourth (55.9 million tons). How about Indonesia? "Indonesia is the second largest country in the world as a producer of plastic waste in the ocean (187.2 million tons)" (Jambeck, 2015). Tiza Mafira, the initiator of the plastic bag diet movement, has researched that every day there are 500 million tons / year of plastic waste in the oceans of Indonesia and this is increasing from previous years (Herfianto, 2019).

Green marketing is one of the company's business forms in environmental conservation efforts to reduce plastic waste. Some retail companies have implemented green marketing activities such as Cotton On, Ramayana, and Indomaret. One concept of its application is the application of paid plastic bags to reduce the use of plastic materials. This trend was also followed by one of Arei Adventure Store Surabaya 3 climbing equipment retailers. The Arei's" go green "image was created through its commitment to the use of paid paper bags as a substitute for the use of plastic-based shopping bags where the paper-based shopping bags are priced at a high enough price of IDR 3,000 for a small size, IDR 6,000 , - for large sizes, and IDR 10,000, - for jumbo sizes. This was done with the aim to familiarize the go green behavior of every consumer who shopped at Arei Adventure Store Surabaya 3.

In addition to this, the company has also implemented green promotion in which marketing promotion prioritizes promotion through social media such as YouTube, Instagram, and Facebook because this is considered to be more environmentally friendly than advertising through print media. Advertising activities in which connect products / services offered with the environment, lifestyle, and corporate image that cares about the environment, where the aim is to inform consumers, persuade, remind, thus consumers will be motivated to make purchasing decisions (Kotler,

\footnotetext{
* Corresponding author.

E-mail address: yanuarb achrul410@gmail.com (Yanuar Bachrul Aqsony)
} 
Aqsony, et.al| Quantitative Economics and Management Studies (QEMS), 2020, 1(3): 194-203

2005 ). On the YouTube channel that takes the famous adventure presenter in Indonesia, namely Panji the Adventurer in which the content on the YouTube channel is also very closely related to adventure activities and nature conservation.

Along with an increasingly competitive market, market participants are demanded to be smart in offering other things, not only always at a discounted price, but also the experience of buying a product. Using the right store atmosphere will create an aesthetic impression and help improve the image of the store / retail in the customer's perception, which will certainly encourage a large buying interest (Kotler \& Keller, 2012). In this case Arei Adventure Store Surabaya 3 as a shop that focuses on selling climbing gear also has its own concept to make customers feel comfortable while in the shop area. Namely the interior design that is dominated by wood and natural stone materials and synthetic grass gives the impression that Arei is a brand that carries the concept of green marketing. The music that is played while the store is operating is instrumental music. In addition, Arei Adventure Store also uses yellow spotlights and LED downlights that give consumers a comfortable and longer shopping time therefore they can create good buying decisions. Not only stop there, Arei has a Move and Adventure tagline that explains its identity as a brand that is concerned with activities related to nature. This slogan is also outlined on the YouTube channel that takes the famous adventure presenter in Indonesia, Panji the Adventurer, in which the contents on the YouTube channel are also very closely related to adventure activities and nature conservation. The slogan and tagline used by Arei are part of the brand image. The understanding of brand image according to the "Marketing Dictionary" (Ali, 2013) is "Brand image is everything about the brand of a product that is thought, felt and visualized by consumers".

The increasing number of similar retail competitors makes Arei encouraged to further enhance their brand image. The role of innovation is very important to form a brand image of the company. According to Kotler and Keller (2012), the definition of brand image is "Perception and beliefs held by consumers. As reflected in the associations held in consumer memory". This means that consumers will embrace perceptions and beliefs in accordance with the experiences they have felt and summarized in their memories. The company is expected to be able to build a good brand image, because this is very influential on consumer intentions to make purchasing decisions. Therefore, the authors are also interested in examining how much influence the brand image on purchasing decisions at adventure equipment stores like Arei.

Whereas the purchase decision itself can be interpreted as the activities of individuals who are directly involved in obtaining and using the goods and services offered. According to Kotler (2008) a purchasing decision is a process carried out by a consumer before coming to a conclusion to buy a product.

From this it can be concluded that this study seeks to see how the influence of green marketing, brand image and store atmosphere on purchasing decisions.

\section{Literature Review}

\section{1. $\quad$ Green marketing}

Green marketing as an environmentally friendly product marketing, combines several activities such as product modification, changes in production processes, packaging, advertising strategies and also raising awareness on compliance marketing between industries (Yazdanifard \& Mercy, 2011). Whereas green marketing refers to the process of selling products or services based on their environmental benefits. Such as environmentally friendly products or services in it or produced in an environmentally friendly way (SS, 2011).

\subsection{Brand image}

Brand image is a perception that lasts long, is formed through experience and is relatively consistent ". Measurement of brand image is very closely related to loyalty and part of the measurement of new consumers become loyal consumers (Schiffman \& Kanuk, 2010). 


\subsection{Store atmosphere}

Store atmosphere or store environment is the atmosphere or store environment that can stimulate the five senses of consumers and affect consumers' perceptions and emotions about the store, according to the statement (Levy \& Weitz, 2012).

\subsection{Buying decision}

Purchasing decision is a process of decision making about a purchase which includes determining what will be purchased or not making a purchase and the decision was obtained by previous activities (Romdonah, 2015).

\subsection{Relationship Between Variables}

\subsubsection{The relationship between green marketing and purchasing decisions}

At present many companies are adopting green marketing strategies in line with the growing number of consumers and organizations that care about the environment (Purnama \& Adi, 2019). The superiority of green marketing strategy will make someone easily believe in a product that can form a buying interest and will later have an impact on purchasing decisions (Agustin, 2015).

\subsubsection{The relationship between brand image and purchasing decisions}

According to Setyaningrum (2014) brand image indicates a strong relationship with purchasing decisions. The better the brand image perceived by consumers, the consumer purchasing decisions will increase.

\subsubsection{Relationship with store atmosphere purchasing decisions}

According to Melisa (2012), the atmosphere is able to influence the enjoyment of consumers in shopping, and is able to create a comfortable and pleasant shopping experience. Consumers will spend the time and money that much because the store atmosphere is good. Therefore, it can be said that the better the store atmosphere management, the better the consumer's perception of the store atmosphere and the greater the consumer's urge to make purchases at the store.

\section{Research Methods}

This research approach uses a quantitative approach to examine specific populations or samples, sampling techniques are generally carried out randomly, data collection uses research instruments, quantitative or statistical analysis with the aim to test predetermined (Sugiyono, 2013).

The object of this research is Arei Adventure Store Surabaya 3. While the subjects in this study are all consumers of Arei Adventure Store Surabaya 3. In this research, it will examined how will be the influence of Green Marketing, Brand Image, and Store Atmosphere on Purchasing Decisions at Arei Adventure Store Surabaya 3.

According to Sugiyono (2012) the population is a generational area that consists of objects or subjects that have certain qualities and characteristics that are determined by researchers to be studied and then conclude. The population in this study is Arei Adventure Store Surabaya 3 consumers.

According Sugiyono (2013) sample is part of the number and characteristics possessed by the population of the. The criteria are set as follows:

1. Customers are at least 19 years old

2. Customers who come to Arei Adventure Store Surabaya. 
Hair et al (2006) suggest that the number of study samples for which the exact population is unknown is at least five times the analyzed variable or indicator. Indicators of this study amounted to 20, the results obtained from the calculation of samples taken in this study determine the number of samples to be at least 100 people.

Based on the data source, the data used in this study are primary data. To obtain this data researchers used a questionnaire. Questionnaire is a data collection technique that is done by giving a set of written questions to respondents to answer (Sugiyono, 2009). Primary data in this study are Arei Adventure Store Surabaya 3 consumers' perception of the effect of green marketing, brand image and store atmosphere on purchasing decisions obtained through questionnaire data.

According to Sugiyono (2013), the questionnaire is a data collection technique that is done by giving a set of questions or written statements to respondents to be answered. Questionnaires can be closed or open questions or statements, can be given to respondents directly or sent via post or internet.

The list of questions in this questionnaire must be in accordance with the problem under study, and obtain data relating to green marketing, brand image, store atmosphere and consumer purchasing decisions Arei Adventure Store Surabaya 3. Technical data in this study uses the analysis technique of multiple linear regression approaches, Assumption Test Classic, Simultaneous Test (Test F), Partial Test (Test t).

\section{Independent Variable}

Independent variables are types of variables that explain or influence other variables.

- Green marketing (X1)

Green marketing here is the consistency of all activities that design services and facilities for the satisfaction of the needs and wants of consumers Arei Adventure Store, with no impact on the environment at all, includes green products, green prices, and green promotion.

- $\quad$ Brand Image (X2)

Brand Image is defined as a set of brand associations that are formed in the minds of consumers. Arei Adventure Store Surabaya 3. Includes product attributes, consumer benefits, brand personality.

- $\quad$ Store Atmosphere (X3)

Store Atmosphere is defined as visual communication, lighting, color, music, and aroma to simulate customer perception and emotional responses and ultimately influence consumer buying behavior. Includes store front display, marquee (symbol), entrance, window display, parking area, floor, lighting and color, aroma and music, price tags, and room temperature

\section{Dependent Variable}

- Buying decision

Consumer purchasing decisions can be interpreted as an action taken by Arei Adventure Store Surabaya 3 consumers in an effort to trigger the need by purchasing Arei products. It includes recognition of needs, information seeking, alternative evaluation.

\section{Result and Discussions}

\subsection{Result}

The results of the study are presented based on observing a number of variables used in the regression model. As explained in the previous chapter, that this study uses three independent variables namely green marketing, brand image, store atmosphere and also uses one dependent variable, namely a purchasing decision. The object of this research is Arei Adventure Store Surabaya 3.

The data used in the calculation of the variables of this study were obtained from a questionnaire that was filled out by Arei Adventure Store Surabaya consumers3. Researchers want to see the effect simultaneously and partially of the variables studied. 
Table 1. Characteristics of Respondents Based on Domicile

\begin{tabular}{cccc}
\hline Domicile & Frequency & Percent (\%) & Cumulative Percent (\%) \\
\hline Surabaya & 69 & 68.4 & 68.4 \\
Sidoarjo & 9 & 8.9 & 77.2 \\
Jombang & 6 & 5.9 & 83.1 \\
Others & 17 & 16.8 & 100 \\
\hline Total & 101 & 100 & \\
\hline
\end{tabular}

Table 2. Characteristics of Respondents Based by Gender

\begin{tabular}{cccc}
\hline Gender & Frequency & Percent (\%) & Cumulative Percent (\%) \\
\hline Man & 64 & 6,4 & 63.4 \\
Woman & 37 & 36.6 & 100 \\
\hline Total & 101 & 100 & \\
\multicolumn{4}{c}{ Table 3. Characteristics of Respondents by Age } \\
\hline Age & Frequency & Percent (\%) & Cumulative Percent (\%) \\
\hline 19-23 years old & 49 & 48.5 & 92.1 \\
24-29 years old & 44 & 43.6 & 100 \\
\hline 30-34 years old & 8 & 7,9 & \\
\hline Total & 101 & 100 &
\end{tabular}

Table 4. Characteristics of Respondents Based on Employment

\begin{tabular}{cccc}
\hline Profession & Frequency & Percent (\%) & Cumulative Percent (\%) \\
\hline Student / Student & 45 & 44.6 & 44.6 \\
Government & 6 & 5.9 & 50.5 \\
employees & & & 93 \\
General employees & 43 & 2.6 & 95 \\
Entrepreneur & 2 & 2 & 97 \\
Trader & 2 & 1 & 98 \\
Farming & 1 & 1 & 100 \\
BUMN employee & 1 & 1 & \\
Marker Review & 1 & 100 & \\
Manager & 101 & & \\
\hline Total & & & \\
\hline
\end{tabular}

Table 5. Characteristics of Respondents Based on Income

\begin{tabular}{cccc}
\hline Income & Frequency & Percent (\%) & Cumulative Percent (\%) \\
\hline <Rp. 3,000,000 & 45 & 44.6 & 44.6 \\
Rp. 3,000,000-Rp. 5,000,000 & 46 & 45.5 & 90.1 \\
> Rp. 5,000,000 & 10 & 9.9 & 100 \\
\hline Total & 101 & 100 & \\
\hline
\end{tabular}

Table 6. Reliability Test Results

Reliability Statistics

\begin{tabular}{cc}
\hline Cronbach's Alpha & N of Items \\
\hline 0.895 & 20 \\
\hline Source: SPSS output data (2020)
\end{tabular}

It can be seen from table 6, the data of this study has a Cronbach's alpha of 0.895 and is above 0.60 , the data of this study can be stated reliable and reliable. 
Table 7. Summary Model

\begin{tabular}{|c|c|c|c|c|c|}
\hline \multicolumn{6}{|c|}{ Summary Model } \\
\hline \multirow[t]{2}{*}{ Model } & & & \multicolumn{3}{|c|}{ Std. Error of the } \\
\hline & $\mathrm{R}$ & R Square & Adjusted R Square & Estimate & Durbin-Watson \\
\hline 1 & $0.680^{\mathrm{a}}$ & 0.462 & 0.446 & 1.07728 & 1.996 \\
\hline
\end{tabular}

Source: SPSS Output Data (2020)

Based on table 7, the coefficient value of $\mathrm{R}>0.5$ is equal to 0.446 . This means that green marketing (X1), store atmosphere (X2), and brand image (X3) variables have a significant effect on purchasing decisions (Y) of $44.6 \%$ while the remaining $55.4 \%$ is influenced by other variables outside the regression model researched.

Table 8. T Test (Partial)

\begin{tabular}{|c|c|c|c|c|c|c|c|c|}
\hline \multicolumn{9}{|c|}{ Table 8. T Test (Partial) } \\
\hline \multirow[t]{2}{*}{ Model } & & \multicolumn{2}{|c|}{$\begin{array}{l}\text { Unstandardized } \\
\text { Coefficients }\end{array}$} & \multirow{2}{*}{$\begin{array}{l}\text { Standardized } \\
\text { Coefficients } \\
\text { Beta }\end{array}$} & \multirow[b]{2}{*}{$\mathrm{T}$} & \multirow[b]{2}{*}{ Sig. } & \multicolumn{2}{|c|}{ Collinearity Statistics } \\
\hline & & $\mathrm{B}$ & Std. Error & & & & Tolerance & VIF \\
\hline \multirow[t]{6}{*}{1} & (Constant) & 1,583 & 1,200 & & 1,319 &, 190 & & \\
\hline & Green &, 104 &, 073 &, 141 & 1,425 &, 157 &, 567 & 1,765 \\
\hline & Marketing & & & & & & & \\
\hline & Brand Image &, 221 &, 093 &, 202 & 2,378 &, 019 &, 769 & 1,300 \\
\hline & Store &, 155 &, 035 &, 458 & 4,458 &, 000 &, 526 & 1,899 \\
\hline & Atmosphere & & & & & & & \\
\hline
\end{tabular}

a. Dependent Variable: Purchase Decision

Source: SPSS output data (2020)

Based on Table 8 in mind that the value of the variable green marketing (X1) of 1,425, a variable of brand image (X2) of 2,378 and a variable store atmosphere (X3) of 4.458.

1. Testing the effect of green marketing on purchasing decisions

The test results obtained $t$ value for the variable of green marketing to buying decision showed $t_{\text {coum }}=1,425$ $<\mathrm{t}_{\text {able }} 1.98472$ significance $0,157>0.05$. Thus the green marketing variable does not have a partial and insignificant effect on purchasing decisions at Arei Adventure Store Surabaya 3.

2. Testing the influence of brand image on purchasing decisions

The test results obtained $\mathrm{t}$ value for the variable of brand image on purchase decisions exhibited $\mathrm{t}_{\text {coum }}=2,378>\mathrm{t}_{\text {table }} 1.98472$ significance $0,019<0.05$. Thus the brand image variable has a partial and significant influence on purchasing decisions at Arei Adventure Store Surabaya 3.

3. Testing the effect of store atmosphere on purchasing decisions

The test results obtained $\mathrm{t}$ value for a variable store atmosphere on purchase decisions displayed $\mathrm{t}_{\text {coum }}=4.458>\mathrm{t}_{\text {wabl }} 1.98472$ significance $0,000<0.05$. Thus the brand image variable has a partial and significant influence on purchasing decisions at Arei Adventure Store Surabaya 3. 
Table 9. F Test Results (simultaneous)

ANOVA $^{\text {b }}$

\begin{tabular}{llrrrrr}
\hline Model & & Sum of Squares & Df & Mean Square & F & Sig. \\
\hline 1 & Regression & 96.755 & 3 & 32.252 & 27.791 & $0.000^{\mathrm{a}}$ \\
& Residual & 112.571 & 97 & 1.161 & & \\
& Total & 209.327 & 100 & & & \\
\hline
\end{tabular}

a. Predictors: (Constant), Store Atmosphere, Brand Image, Green Marketing

b. Dependent Variable: Purchase Decision

Source: SPSS output data (2020)

Based on data from Table 9 is known that the obtained $\mathrm{F}_{\text {coum }}=27.791$ while the value of $\mathrm{F}_{\text {tuble }}$ obtained by 2,70 . Thus $\mathrm{F}$ count $27.791>\mathrm{F}$ table 2,70 and significant value $0.000<0.05$ so that it can be concluded green marketing (X1), brand image (X2) and store atmosphere (X3) are simultaneously positive and significant impact on the purchase decision (Y) on Arei Adventure Store Surabaya 3.

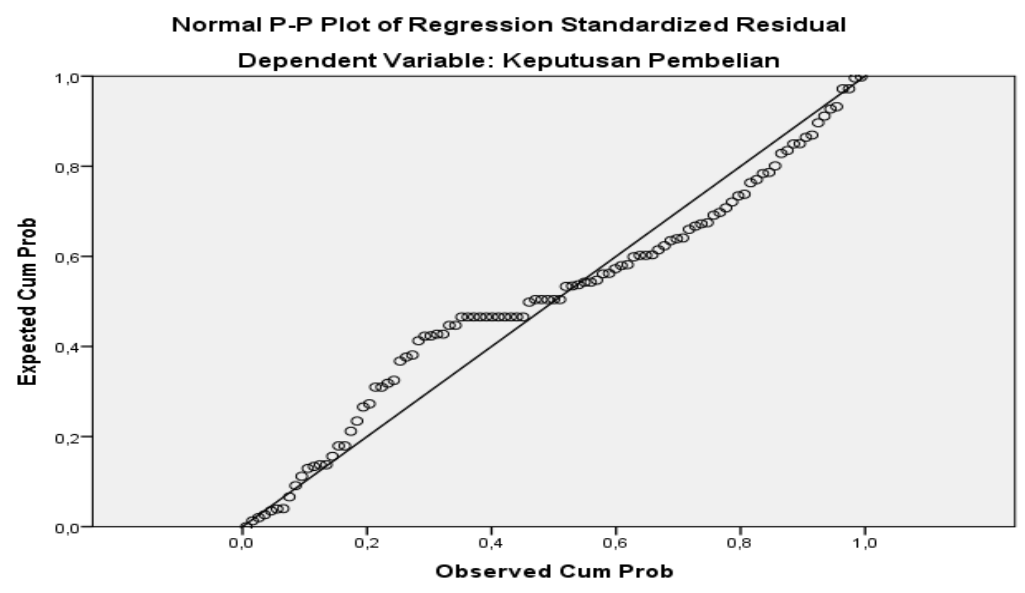

Figure 1. Normality Test Results

Source: SPSS output data (2020)

In Figure 1 it can be seen that the standardized normal probability plot of regression graph shows normal graph patterns. This can be seen from the points that spread around the diagonal lines and diagonal lines from the lower left to the upper right. Therefore it can be concluded that regression model was fit for use because they meet the assumptions of normality.

Based on table 10 it is clear that the regression model does not experience Multicollinearity disorder. This can be seen in the tolerance value of each independent variable greater than 0.1. VIF calculation results also show that the VIF value of each independent variable is less than 10. Thus it can be concluded that there is no Multicollinearity between independent variables in the regression model. 
Table 10 Multicollinearity Test Results

Coefficients $^{\mathrm{a}}$

\begin{tabular}{llccccccccc}
\hline Model & & \multicolumn{2}{c}{$\begin{array}{c}\text { Unstandardized } \\
\text { Coefficients }\end{array}$} & \multicolumn{2}{c}{$\begin{array}{c}\text { Standardized } \\
\text { Coefficients }\end{array}$} & & \multicolumn{3}{c}{$\begin{array}{c}\text { Collinearity } \\
\text { Statistics }\end{array}$} \\
& & B & Std. Error & Beta & t & Sig. & Tolerance & VIF \\
\hline 1 & 1.583 & 1.200 & & 1,319 &, 190 & & \\
& (Constant) & 0.104 & 0.073 & 0.141 & 1,425 &, 157 &, 567 & 1,765 \\
& Green Marketing & 0.221 & 0.093 & 0.202 & 2,378 &, 019 &, 769 & 1,300 \\
& Brand Image & 0.155 & 0.035 & 0.458 & 4,458 &, 000 &, 526 & 1,899 \\
\hline & Store Atmosphere & & & & & & & & & \\
\hline
\end{tabular}

a. Dependent Variable: Purchase Decision Source: SPSS output data (2020)

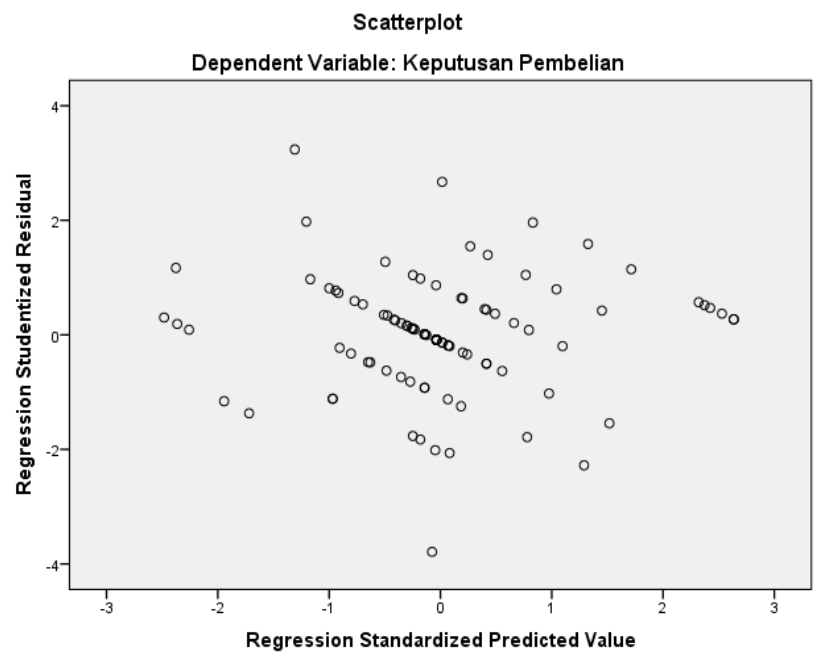

Fig. 2. Heteroscedasticity Test Results

Based on Fig. 2 scatterplot shows the points spread evenly so that it meets the assumption of heteroscedasticity.

\subsection{Discussion}

1. Testing the effect of green marketing on purchasing decisions.

H1: Does green marketing partially have a significant effect on purchasing decisions at Arei Adventure Store Surabaya 3 ?

Based on the test results obtained by the $t$ value for the green marketing variable on the purchase decision shows the value of $\mathrm{t}$ count $=1.425<\mathrm{t}$ table 1.98472 with a significance of $0.157>0.05$ meaning it is not significant because consumers do not care about green marketing conducted by Arei Adventure Store Surabaya 3

2. Testing the influence of brand image on purchasing decisions.

H2 : Does Brand Image partially have a significant effect on Purchasing Decisions at Arei Adventure Store Surabaya 3 ? 
Based on the test results obtained $t$ value for the brand image variable on the purchase decision shows the value of $\mathrm{t}$ count $=2.337>\mathrm{t}$ table 1.98472 with a significance of $0.019<0.05$ meaning this indicates that the brand image has a significant effect on purchasing decisions at Arei Adventure Store Surabaya 3 because the better the brand image the brand image is built, the higher the level of consumer purchasing decisions.

3. Testing the effect of store atmosphere on purchasing decisions.

H3 : Does Store Atmosphere partially have a significant effect on Purchasing Decisions at Arei Adventure Store Surabaya 3 ?

Based on the test results obtained by $\mathrm{t}$ count for store atmosphere on purchasing decisions shows the value of $\mathrm{t}$ count $=4.458>\mathrm{t}$ table 1.98472 with a significance of $0,000<0.05$ meaning this indicates that the store atmosphere has a significant effect on purchasing decisions at Arei Adventure Store Surabaya 3 where the better store atmosphere Arei Adventure Store Surabaya 3, the higher the level of consumer purchasing decisions.

4. Testing the effect of green marketing, brand image, store atmosphere on purchasing decisions.

H4: Is there a significant influence simultaneously on Green Marketing, Brand Image, and Store Atmosphere on Purchasing Decisions on Arei Adventure Store Surabaya 3?

Based on the results of simultaneous hypothesis testing (Test F) of the independent variables (free) namely green marketing, brand image, and store atmosphere simultaneously affect the dependent variable (bound) of purchasing decisions. This is evidenced from the significance value of 0,000 or less than 0.05 and $\mathrm{F}_{\text {count }}=27.791$ while the $\mathrm{F}$ value of the $\mathrm{F}_{\text {table }}$ is 2.70 . Thus $\mathrm{F}_{\text {count }}: 27.791>\mathrm{F}_{\text {table }}: 2.70$.

\section{Conclusions}

Based on result and discussion in this study, we can conclude that:

1) Green marketing (X1) has no significant effect on purchasing decisions ( $\mathrm{Y})$. Where the value of $t_{\text {arithmeic }}=1.425$ $<\mathrm{t}_{\text {table }} 1.98472$ with a significance of $0.157>0.05$ which is not significant meaning green marketing does not affect purchasing decisions.

2) Brand image (X2) influences the significance of purchasing decisions (Y). Where the value of $\mathrm{t}_{\text {coum }}=2.337>$ from $\mathrm{t}_{\text {able }} 1.98472$ with a significance of $0.019<0.05$ means significant. . This can mean that consumers agree that brand image influences purchasing decisions at Arei Adventure Store Surabaya 3

3) Store Atmosphere (X3) partially influences the purchase decision (Y). Where the value of $t_{\text {anithrexic }}=4.458>$ from $\mathrm{t}_{\text {able }} 1.98472$ with a significance of $0,000<0.05$ means significant. This means that store atmosphere affects consumer purchasing decisions ..

4) Variable green marketing (X1), brand image (X2) and store atmosphere (X3) simultaneously influence the purchase decision $(\mathrm{Y})$ with a significant value smaller than 0.05 which is equal to 0,000 .

\section{References}

Ali, H. (2013). Marketing and Selected Cases. Yogyakarta: CAPS (Center for Academic Publishing Service).

Herfianto. (2019). Diet Plastic Bags for the Earth, How to Do? Retrieved November 10, 2019, from https://www.liputan6.com/global/read/4086618/diet-kantong-plastik-for-bumi- how-how

Jambeck, JR (2015). MARINE POLLUTION Plastic waste input from land into the ocean. sciencemag.org.

Kotler \& Keller. (2012). Marketing Management. Issue 12. Jakarta: Erlangga.

Kotler, P. (2005). Marketing Management, Volume I and II. Jakarta: PT Gramedia Group Index.

Levy, M., \& Weitz, BA (2012). Retailing Management. New York America: McGraw-Hill.

Purnama, PA, \& Adi, NR (2019). Green Marketing and Brand Quality as Predictors of Consumer Behavior and Its Impact on Product Purchasing Decisions. Journal of Management and Business . 
Romdonah, R. (2015). The Effect of Product Innovation, Price, and Brand Image on Purchasing Decisions of Honda Beat Motorcycles (Case Study on Consumers of Honda Pratama Kurnia Asih Customers) , 2.

Schiffman, L., \& Kanuk, L. (2010). Consumer Behavior (10th ed). New Jersey, Pearson Prentice Hall.

SS, Bukhori. (2011). Green Marketing and its impact on consumer behavior. 375-383.

Sugiyono (2012). Educational Research Methods Quantitative Approach ,. Qualitative, and R\&D. Bandung: Alfabeta.

Sugiyono (2013). Educational Research Methods Quantitative Approach ,. Qualitative, and R\&D. Bandung: Alfabeta.

Yazdanifard, R., \& Mercy, IE (2011). The impact of Green Marketing on Customer satisfaction and Environmental safety. IACSIT Press, Singapore . 